\title{
Guidance on the Application of \\ Quality Assurance for \\ Characterizing a Low-Level \\ Radioactive Waste Disposal Site
}

Final Report

Manuscript Completed: October 1990

Date Publistied: October 1990

C. i. Pittiglio, Jr., R. J. Starmer, D. Hedges

Division of Low-Level Waste Management and Decommissioning

Office of Nuclear Material Safety and Safeguards

U.S. Nuclear Regulatory Commission

Washington, DC 20555
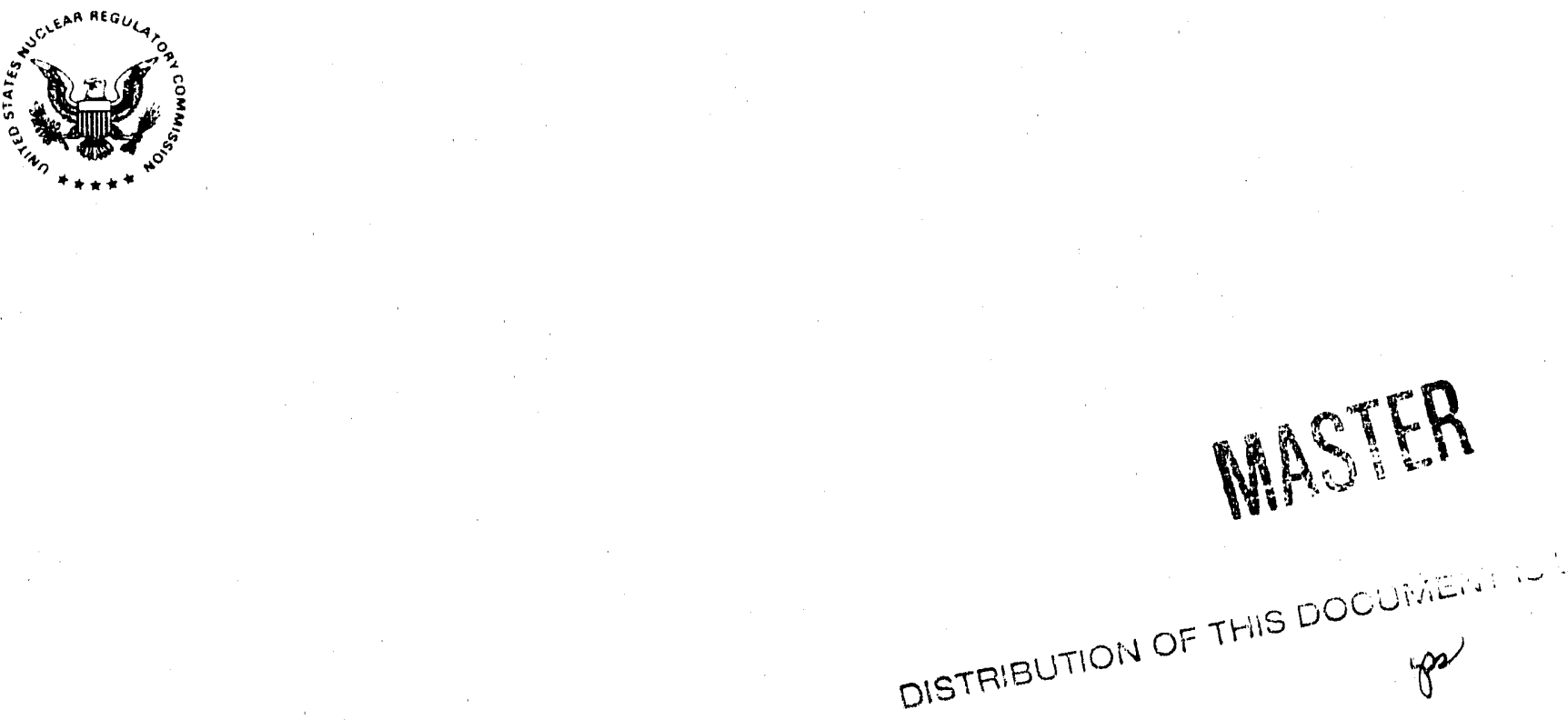


\begin{abstract}
This document provides the Nuclear Regulatory Commission's staff guidance to an applicant on meeting the quality control (QC) requirements of Title 10 of the Code of Federal Regulations, Part 61, Section 61.12 (10 CFR 61.12), for a low-level waste disposal facility. The QC requirements combined with the requirements for manage-

rial controls and audits are the basis for developing a quality assurance (QA) program and for the guidance provided herein. QA guidance is specified for site characterization activities necessary to meet the performance objectives of 10 CFR Part 61 and to limit exposure to or the release of radioactivity.
\end{abstract}




\section{CONTENTS}

Page

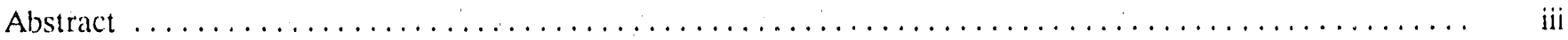

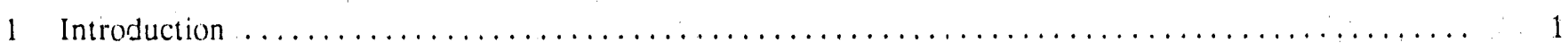

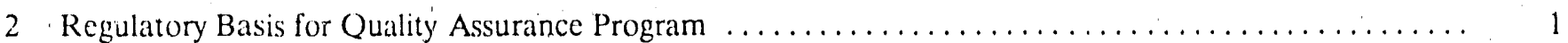

3 Identification of Parameters and Tests for Evaluating a Disposal Site $\ldots \ldots \ldots \ldots \ldots \ldots \ldots \ldots \ldots \ldots 2$

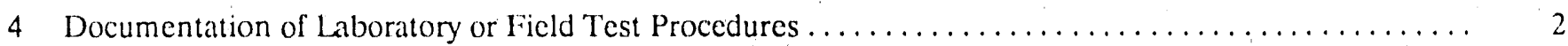

5 Qualifications and Training for Personnel Conducting Site Characterization Activities ............ 7

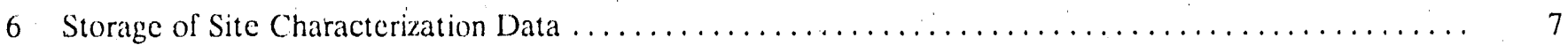

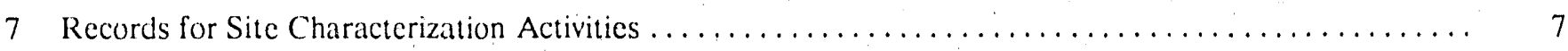

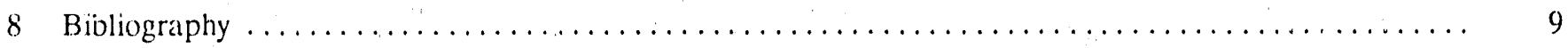

Appendix A Summary of Public Comments on Draft Technical Position Statement $\ldots \ldots \ldots \ldots \ldots \ldots . . \quad r$ 


\section{QA GUIDANCE FOR CHARACTERIZING A LLRW DISPOSAL SITE}

\section{INTRODUCTION}

The United States Congress passed laws in 1980 and 1985 that require Statcis to take specific actions to deal with the low-level radioactive waste generated by facilities operating within their boundaries. The 1980 law (Public Law 96-573, The Low-Level Radioactive Waste Policy Act) specifies that each State will be responsible for disposing its own radioactive waste after January 1,1986 ; authorizes States to join together to form regional compacts; and authorizes those compacts to prohibit disposal of lowlevel radioactive waste generated outside the regional compact. The 1985 amendment (Public Law 99-240, The Low-Level Radioactive Waste Policy Amendments Act) cxtended the date to January 1993. This amendment imposes intermediate milestones that the States are required to meet to demonstrate progress and authorizes the States accepting this waste for disposal to impose a surcharge on the existing waste disposal costs.

In an attempt to assist the States in meeting these milestones, the Nuclear Regulatory Commission (NRC) has develcped and issued several documents providing guidance on the development of a low-level radioactive waste disposal facility. This document provides guidance to an applicant on the quality assurance principles for characterizing a disposal site; it is not a regulatory requirement. This document does not address all of the 18 criteria defined in NUREG-1293, Quality Assurance Guidance for Low-Level Radioactive Waste Disposal Facility; however, it provides some additional guidance on the criteria common to all site characterization activities. In addition, the $\mathrm{NRC}$ is in the process of developing quality assurance (QA) guidance in several other related areas and is continuing to conduct workshops on the QA principles to be used by an applicant for license of a low-level radioactive waste disposal facility, including workshops for site characterization activities.

\section{REGULATORY BASIS FOR QUALITY ASSURANCE PROGRAM}

Title 10 of the Code of Federal Regulations, Part 61, Section 61.12(j) (10 CFR 61.12(j)), requires that a license application for a low-level radioactive waste (LLRW) disposal facility include a description of the quality control (QC) program to be applied to determining the natural characteristics of a disposal site. The regulation also requires a QC program during design, construction, operation, and closure of the LLRW land disposal facility and the receipt, handling, and emplacement of waste. Audits and managerial controls must be included. The purpose of the QC program, audits, and managerial controls required by 10 CFR 61.12(j) is to ensure a planned, organized, and documented approach to meeting the performance objectives and technical requirements of $10 \mathrm{CFR}$ Part 61. These requirements provide the bases for the development of a QA program and the guidance provided herein.

The regulatory requirements for a QC program, audits, and managerial controls, apply to the preoperational phase, the operational phase, the site closure phase, and the post-closure institutional control phase. These requirements cover all activities, structures, systems, or components whose failure could result in not meeting the performance objectives of 10 CFR Part 61 or not limiting the exposure to or the release of radioactivity. A QA program includes a multidisciplinary system of management controls supported by quality verification and overview a vities that demonstrate completeness and appropri- ess of achieved quality and serves as a mechanism to meet the requirements for audits and managerial controls. The applicant should develop and implement an effective QA program before starting site characterization activities and, as the licensee, should continue an effective QA program until the license has been trans:erred or terminated. Site characterization is one of the initial and most significant activities for determining the suitability of a site and demonstrating performance of an LLRW disposal site; therefore, it is important that proper quality assurance procedures are developed and applied to all site characterization activities.

To ensure that the site meets regulatory requirements, an applicant should have management controls in place at the beginning of the investigation of the disposal site's characteristics and before performing the analyses to establish a base for its suitability. The applicant must be prepared to demonstrate in the license application that the proposed LLRW disposal site, disposal site design, land disposal facility operations (including equipment, facilities, and procedures), disposal site closure, and postclosure institutional control are adequate to demonstrate that the performance objectives and technical requirernents of 10 CFR Part 61 will be met. The applicant should expect that the validity of information contained in the license application will be challenged during licensing review and hearing, and the applicant must be prepared to defend the validity of the data, the analyses, and the conclusions reached. A well-designed and effectively implemented QA program provides the disciplined approach, verification of results, and records to support the positions taken in the license application. 


\section{IDENTIFICATION OF PARAMETERS AND TESTS FOR EVALUATING A DISPOSAL SITE}

As part of defining the quality assurance procedures for a license application, it is first necessary to identify the most significant parameters for characterizing a site. This will provide an insight into the magnitude of work required for site characterization. Table 1 lists the tests and procedures necessary to evaluate or document approximately 70 important site parameters for licensing an LLWR disposal sitc.

A detailed discussion of each of these parameters is provided in NUREG/CR-2700, Parametes' for Characterizing Sites for Disposal of Low-Level Radioacti'c Waste. Most of the tests and procedures given in Table 1 are accepted standard methods-such as those endorsed by the American Society for Testing and Materials (ASTM) - that are used nationwide and are listed in the column designated "standard method." Other tests, designated as "formalized guidance," provide documented direction for conducting activitics related to site characterization. In addition to the standard methods and formalized guidance, an additional category of methods involves the use of existing data sources or recognized correlations used in place of new testing or documentation. It may be necessary to develop unique procedures for site-specific testing and measuring. NUREG/CR-3038, Tests for Evaluating Sites for Disposal of Low-Level Radioactive Waste, provides a description of most of the tests identified in Table 1. The U.S. Department of Energy Site Characterization Handbook, DOE/LLW-67T, also provides information on parameters and tests for characterizing an LLRW disposal site.

Because of much diversity in materials and conditions between many sites across the country, it is impossible to list all the parameters required to characterize a site. Table 1 provides only a partial listing of parameters that characterize an LLRW disposal site. NUREG-0902, Site Suitability, Selection and Characterization, provides detailed guidance on all parameters required to characterize a disposal site, including ecology, social economics, land use, and cultural resources, as well as those parameters listed in Table 1.

Section 5 provides guidance on qualifications and training for personnel conducting site characterization activities. It is important to emphasize that characterization activities-such as mapping, logging, sampling, testing, interpretation, and analysis - be conducted by technically qualified personncl.

The regulatory review of a license application against the requirements of 10 CFR Part 61 will determine that the health and safety of the public is ensured. An evaluation of the methodology used for the site characterization process is one of the principal mechanisms used to make that finding. Therefore, it is paramount that the applicant's planning process reflect the intent to collect and analyze data for that purpose. The license application can only be approved when the performance objectives and technical requirements of 10 CFR Part 61 are met and when the application irrefutably demonstrates that the health and safety of the public are protected.

The most common (and most costly) crror applicants make is to not carcfully plan the investigations needed to characterize the site with a goal of assuring that the license application will be technically complete, procedurally defensible, and supported by fully traccable documentation of the quality of the technical work. A well-planned and implemented QA program will ensure that organizational responsibilities are assigned, personnel are adequately trained, and plans and proceclures are written before site characterization activities are started.

In planning the tests to be conducted during site characterization, the applicant must assure that the resulting data will provide the information required to conduct a licensing assessment. 'The liecnsing assessment includes the initial step in site characterization of establishing the present le', el of understanding about the site followed by identification of the issues related to meeting performance objectives and technical requirements of $10 \mathrm{CFR}$ Part 61, and finally, collecting data required by regulation and needed to support a complete and technically defensible license application. The QA program should be an integral part of the test program to ensure adequate planning, equipment selection and use, training of personnel, sample handling and storage, and records of testing.

\section{DOCUMENTATION OF LABORATORY OR FIELD TEST PROCEDURES}

Testing procedures for characterizing an LIJRW disposal site generally are classified into two (ategories. The first category would be described as standardized tests that have been developed by a standards-setting organization such as ASTM. The second category of tests are those that have not been codified by a standards-setting organization but are nationally recognized and considered state of the art. Such tests are those recommended by liederal Government organizations such as the Army Corps of I:ngineers, the Environmental Protection Agency, and the United States Geological Survey. The applicant may adapt tests or other guidance to site-specilic eonditions or to incorporate newer, more accurate or sensitive techniques. Regardless of the type of test conducted or whether the test is conducted in the field or laboratory, it 
Table 1 Testing and other information to characterize LLRW sites

\begin{tabular}{|c|c|c|c|}
\hline Parameter & $\begin{array}{l}\text { Standard } \\
\text { method* }\end{array}$ & Formalized guidance & Existing data \\
\hline Air pressure & $\begin{array}{l}\text { ASTM } \\
- \\
-\end{array}$ & $\overline{-}$ Barometric observations & $\begin{array}{l}- \\
\text { Weather records }\end{array}$ \\
\hline Air temperature & $\overline{-}$ & Thermometric observations & Weather records \\
\hline Anisotropy & $\overline{-}$ & $\overline{-}$ & $\begin{array}{l}\text { Geological criteria } \\
\text { Permeabilities }\end{array}$ \\
\hline Apparent velocity & - & Tracer studies & - \\
\hline Atterberg limits & $\begin{array}{l}\text { ASTM } \\
\text { CE }\end{array}$ & $\overline{-}$ & - \\
\hline Burial unit boundaries & - & Plane surveying & - \\
\hline Collapse susceptibility & $\begin{array}{l}\mathrm{CE} \\
- \\
-\end{array}$ & $\begin{array}{l}- \\
- \\
-\end{array}$ & $\begin{array}{l}\text { Geological criteria } \\
\text { Grain-size data }\end{array}$ \\
\hline Compaction relation & ASTM & - & - \\
\hline Consolidation relation & $\mathrm{CE}$ & - & - \\
\hline Dispersion & - & Breakthrough curves & - \\
\hline Electrical resistivity & $\begin{array}{l}- \\
- \\
-\end{array}$ & $\begin{array}{l}\text { Total salinity of soil } \\
\text { Surface resistivity survey } \\
\text { Borehole resistivity survey } \\
-\end{array}$ & $\begin{array}{l}- \\
- \\
\text { Specific conductance }\end{array}$ \\
\hline Erodibility & $\begin{array}{l}\mathrm{CE} \\
-\end{array}$ & $\overline{-}$ & Agronomical criteria \\
\hline Evapotranspiration & $\begin{array}{l}- \\
-\end{array}$ & $\begin{array}{l}\text { Evaporimetric or lysimetric } \\
\text { observations }\end{array}$ & Weather records \\
\hline Extended site boundary & - & - & Technical review \\
\hline Flow direction & $\overline{-}$ & Tracer studies & $\overline{\text { Well data }}$ \\
\hline Frost heaving & - & - & $\begin{array}{l}\text { Geological criteria } \\
\text { Grain-size data }\end{array}$ \\
\hline Gaseous constituents & $\begin{array}{l}\text { APHA } \\
\text { ASTM }\end{array}$ & - & $\begin{array}{l}- \\
-\end{array}$ \\
\hline Geomorphology & - & - & Geological criteria \\
\hline Grair-size distribution & $\begin{array}{l}\text { CE } \\
\text { ASTM }\end{array}$ & $\overline{-}$ & - \\
\hline Groundwater chemistry & $\begin{array}{l}\text { APHA } \\
\text { EPA } \\
\text { ASTM } \\
\text { GS } \\
-\end{array}$ & 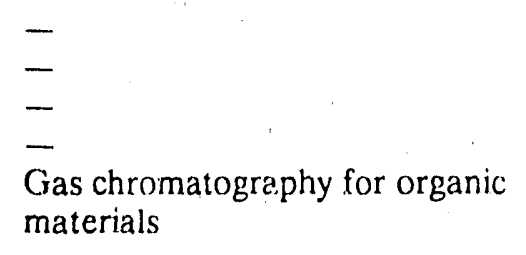 & $\begin{array}{l}- \\
- \\
- \\
-\end{array}$ \\
\hline
\end{tabular}


Table 1 (Continued)

\begin{tabular}{|c|c|c|c|}
\hline Parameter & $\begin{array}{l}\text { Standard } \\
\text { method* }\end{array}$ & Formalized guidance & Existing data \\
\hline $\begin{array}{l}\text { Groundwater system and } \\
\text { boundaries }\end{array}$ & - & - & Gcological criteria \\
\hline Hydraulic conductivities & $\begin{array}{l}\text { ASTM } \\
\text { CE } \\
\text { BR } \\
- \\
- \\
-\end{array}$ & $\begin{array}{l}- \\
- \\
\text { Pump tests } \\
- \\
-\end{array}$ & $\begin{array}{l}\overline{-} \\
\overline{-} \\
\overline{-} \\
\text { Geological criteria } \\
\text { Grain-size data. }\end{array}$ \\
\hline $\begin{array}{l}\text { Hydraulic potentials and } \\
\text { pressures }\end{array}$ & - & $\begin{array}{l}\text { Well logging } \\
\text { Piezometric determination }\end{array}$ & - \\
\hline Immediate site boundary & - & Technical review & - \\
\hline Infiltration capacity & ASTM & - & $\overline{\text { Curve number estimation }}$ \\
\hline Ion exchange capacity & $\overline{-}$ & $\begin{array}{l}\text { Saturation method } \\
\text { Mehlich method }\end{array}$ & - \\
\hline Lithology and soils & - & - & Geological criteria \\
\hline Material color & ASTM & $\overline{\text { Color chart method }}$ & - \\
\hline Material densities & $\begin{array}{l}\text { ASTM } \\
\text { CE } \\
-\end{array}$ & 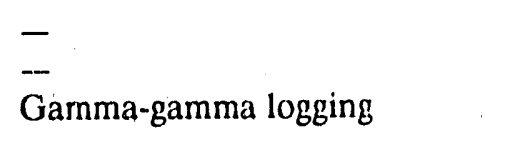 & $\underline{-}$ \\
\hline Material radioactivity & $\begin{array}{l}\overline{-} \\
\overline{A S T M} \\
\mathrm{DE}\end{array}$ & $\begin{array}{l}\text { Borehole gamina survey } \\
\text { Gamma spectral logging } \\
-\end{array}$ & $\begin{array}{l}- \\
- \\
-\end{array}$ \\
\hline Material temperature & $\underline{-}$ & Thermistor readings & Water temperature \\
\hline Material variability parameter & - & $\begin{array}{l}\text { Standard deviation method } \\
\text { Range determination }\end{array}$ & - \\
\hline Material zone boundaries & - & $\begin{array}{l}\text { Detailed logging, sampling, and } \\
\text { arialysis }\end{array}$ & - \\
\hline $\begin{array}{l}\text { Mineralogy and clay } \\
\text { mineralogy }\end{array}$ & $\begin{array}{l}\text { ASTM } \\
-\end{array}$ & $\begin{array}{l}\bar{X} \text {-ray diffraction } \\
\text { Petrog zphy }\end{array}$ & $\begin{array}{l}- \\
-\end{array}$ \\
\hline $\begin{array}{l}\text { Monument and point } \\
\text { positions }\end{array}$ & $\begin{array}{l}\text { NOAA } \\
-\end{array}$ & Plane surveying & $\overline{-}$ \\
\hline Oxidation-reduction potential & - & Platinum/hydrogen electrode & $\overline{\text { Geological criteria }}$ \\
\hline Partition coefficients & - & $\begin{array}{l}\text { Batch leach testing } \\
\text { Column test } \\
-\end{array}$ & $\begin{array}{l}- \\
\overline{\text { Geochemical criteria }}\end{array}$ \\
\hline
\end{tabular}

"See footnote at end of table.

NUREG-1383 
Table 1 (Continued)

\begin{tabular}{|c|c|c|c|}
\hline Parameter & $\begin{array}{l}\text { Standard } \\
\text { method* }\end{array}$ & Formalized guidance & Existing data \\
\hline Penetration parameter & ASTM & - & - \\
\hline Permeability function & - & Instantaneous profile & - \\
\hline Pore water age & $\begin{array}{l}- \\
- \\
-\end{array}$ & $\begin{array}{l}\text { Radioisotopic ratios } \\
\text { Stable isotope test } \\
\text { Conductivity test } \\
\text { Groundwater chemistry }\end{array}$ & $\begin{array}{l}- \\
-\end{array}$ \\
\hline Porosities and void ratio & $\begin{array}{l}\mathrm{CE} \\
- \\
-\end{array}$ & $\begin{array}{l}\text { Acoustic logging } \\
\text { Nuclear logging }\end{array}$ & $\begin{array}{l}- \\
\overline{-} \\
\text { Geological criteria }\end{array}$ \\
\hline Precipitation & $\overline{-}$ & Rain gauge observations & $\begin{array}{l}\text { Weather records } \\
-\end{array}$ \\
\hline Rebound Index & CE & $\overline{-}$ & Geotechnical criteria \\
\hline Recharge and discharge areas & - & - & Geological criteria \\
\hline Rock classification & $\begin{array}{l}\text { ASTM } \\
- \\
-\end{array}$ & $\begin{array}{l}\text { Durability test } \\
- \\
-\end{array}$ & $\begin{array}{l}- \\
\text { Seismic velocity } \\
\text { Core logging indices }\end{array}$ \\
\hline Runoff & $\overline{-}$ & $\begin{array}{l}\text { Stream gauging } \\
-\end{array}$ & Curve number estimation \\
\hline Seepage velocity & -- & Tracer studies & - \\
\hline Seismic velocity & $\overline{-}$ & $\begin{array}{l}\text { Surface survey } \\
\text { Borehole survey }\end{array}$ & $\begin{array}{ll}- \\
-\end{array}$ \\
\hline Shrinking-swelling parameter & ASTM & $\overline{-}$ & $\overline{\text { Geological criteria }}$ \\
\hline Soil classification & $\begin{array}{l}\text { ASTM } \\
-\end{array}$ & $\begin{array}{l}\text { Soil taxonomy } \\
\text { Textural method }\end{array}$ & $\begin{array}{l}- \\
- \\
-\end{array}$ \\
\hline Soil organics & - & Sample ignition method & - \\
\hline Soil pH and acidity & $\begin{array}{l}\text { ASTM } \\
-\end{array}$ & $\overline{\text { Titration }}$ & - \\
\hline Soil solubles & $\begin{array}{l}\text { EPA } \\
\text { APHA }\end{array}$ & $\overline{-}$ & $\overline{-}$ \\
\hline Specific gravity & $\begin{array}{l}\text { ASTM } \\
\text { CE }\end{array}$ & - & - \\
\hline Storativity & $\begin{array}{l}- \\
-\end{array}$ & $\begin{array}{l}\text { Pump test } \\
\text { Neutron logging } \\
-\end{array}$ & $\overline{-}$ \\
\hline Stratigraphy & - & - & - \\
\hline Strength & $\mathrm{CE}$ & - & - \\
\hline
\end{tabular}


Table 1 (Continued)

\begin{tabular}{|c|c|c|c|}
\hline Parameter & $\begin{array}{l}\text { Standard } \\
\text { method }{ }^{*}\end{array}$ & Formalized guidance & Existing data \\
\hline Structure & - & - & Geological criteria \\
\hline Suction pressure function & ASTM & - & - \\
\hline Suction pressures & $\underline{-}$ & $\begin{array}{l}\text { Tensiometric determination } \\
\text { Psychromatric determination } \\
\text { Porous element test }\end{array}$ & $\begin{array}{l}- \\
-\end{array}$ \\
\hline Surface water chemistry & - & - & - \\
\hline $\begin{array}{l}\text { Surface water system and } \\
\text { boundaries }\end{array}$ & - & - & Geological criteria \\
\hline Transmissivity & - & Pump test & - \\
\hline Visual description & ASTM & - & - \\
\hline Water content & ASTM & - & - \\
\hline Water-holding parameters & - & . & $\begin{array}{l}\text { Agronomic data } \\
\text { Suction pressure function }\end{array}$ \\
\hline Water zone boundaries & $\overline{-}$ & $\begin{array}{l}\text { Borehole logging } \\
\text { Water table measurements } \\
\text { - }\end{array}$ & $\begin{array}{l}- \\
\text { Water contents }\end{array}$ \\
\hline Wind speeds and directions & - & $\begin{array}{l}\text { Anemometer and vane } \\
\text { measurements }\end{array}$ & Weather records \\
\hline
\end{tabular}

-ASTM = American Society of Testing and Materials; CE $=$ Corps of Engineers; APHA = American Public Health Association; EPA $=$ Environmental Protection Agency; GS = Geological Survey; BR = Bureau of Reclamation; DE = Department of Energy; and NOAA = National Oceanic and Almospheric Administration

is an absolute necessity that the procedures for conducting the selected test be in writing and clearly define how the test is to be conducted. For tests modified from standard tests or commonly accepted tests or for tests developed for a specific site, the basis for the modification and its use should be documented.

At the time of licensing, the documented procedures and records to verify that work was performed in accordance with the procedures will be the means to demonstrate that the tests were properly performed and the data collected are valid. At a minimum the test procedures should contain:

- a description of the objectives

- $\quad$ test equipment to be used

- $\quad$ prerequisites for performing the tests, including any special conditions to be used, any special equipnient, or any special calibration required to conduct the tests
- step-by-step instructions, including reference to any established standards for conducting the test

- acceptance criteria or instructions to evaluate the test results to ensure that either the field or laboratory test has been properly conducted

- recording date

- identification of person performing the test

- as-found conditions

- corrective actions performed, if any

Where either field or laboratory tests are to be witnessed, the procedure should identify hold points in the testing sequence to permit witnessing and documentation and should include appropriate approval for the work to continue beyond the hold point.

A properly planned and implemented QA pregram will ensure that tests are planned and conducted as described above. 


\section{QUALIFICATIONS AND TRAINING FOR PERSONNEL CONDUCTING SITE CHARACTERIZATION AC'TIVITIES}

'To ersure that the tests for characterizing an LLRW disposal site are properly conducted, it is necessary for the applicant to define the qualifications for the persons conducting these tests and to implement a training program to assure an adequate number of personnel are available to perform the required tests.

The minimum capabilities that qualify personnel to perform a test should be specified in writing. The document defining the qualifications of personnel performing the tests should include, as a minimum, the following information:

- cmployer's name

- identification of person performing test

- tests personnel are qualified to perform

- bases for qualification, including

- records of education, experience, and training

- results of qualification test, when appropriate

- results of periodic evaluations

- results of physical examinations, when required

- date of certification and date of expiration of certification

Properly conducted tests performed by qualified personnel will provide the basis for the applicant to defend the validity of the information in a license application if challenged during a licensing review or hearing.

The training program also should include, as a minimum, the following information:

- provisions about the technical objectives of the project for personnel performing the tests

- the codes and standards that are to be used

- the current status of the procedures developed for unique tests

- the quality assuraree elemerts that are to be employed

Where the need for formal training programs are determined for tes.s, such training attivities should be conducted as necessary to qualily personnel who perform these tests. On-the-job participation should be included, with emphasis on first-hand experience gained through actual performance of these tests.

\section{STORAGE OF SITE CHARACTERIZATION DATA}

The purpose of defining the storage procedures for data (including samples) collected during site characterization is to minimize the possibility of damage or lowering the quality of the data as a result of corrosion, contamination, deterioration, or physical damage from the time the data are collected. This also will ensure that the data are available at the time of licensing. The applicant may elect to develop classification levels for items to be stored on the basis of the environmental conditions under which the samples must be stored.

Quality assurance procedures should provide for overvicw of the data collection and storage process to ensure that planned steps for collection and storage are followed consistently.

Before storing field data, a written storage procedure should be prepared and appropriate personnel should be trained in its use. The QA procedures should include as a minimum:

- a description of the storage area

- a system for marking and identifying the data

- a method for verifying that the data stored is in agreement with the documentation transmitting the data

- a method for maintaining control of the data

- identification of special conditions (e.g., temperature, humidity, and vapor-proof barriers) required for storage of the data

- a description of the housekecping practices necessary to maintain the facility where data samples are stored

- procedures or measures to prevent rodents and other small animals from entering indoor storage areas to minimize possible contamination and damage of stored material

- periodic inspection procedures to ensure the storage areas are being maintained in accordance with procedures

\section{RECORDS FOR SITE CHARACTERIZATION ACTIVITIES}

The purpose of maintaining $Q A$ records is to furnish evidence that site character ization activities affecting quality have been properly performed. QA records shoulc be 
considered completed documents that furnish evidence of the quality of the test or activity. Samples, such as geologic, hydrologic, and environmental, that are required to be maintained are considered $Q A$ records. The applicant should assure identification, storage, maintenance, traceability, legibility, and retrievability of $Q A$ records.

Records that furnish evidence of site characterization activitics affecting quality include, but are not limited to, operating logs; results of reviews, inspections, tests, and audits; monitoring of work performance; and material analyses. The records also should include closely related data such as qualification of personnel, procedures, and equipment.

Inspection and test records should, at a minimum, identify the inspector or data recorder, the type of obscrvation, the results, the acceptability, and the corrective action taken, with any deficiencies noted, In addition, these records should include all related QA activities. These activitics include review of nonconformance reports, corrective action reports, audit and surveillance reports, inspection reports, plans, procedures, and other documents such as tclecons, specifications, technical data, books, maps, pho* tographs, data sheets, and magnetic media and other materials that provide data and document quality, regardless of the physical form or characteristic. A "completed record" is a document that will either receive no more entries or whose revision would normally consist of reissuance of the document; it is signed and dated by the originator and, as applicable, by personnel authorized to approve the document.

Bound notebooks should be the primary record document for ficld survey work, providing a chronology of significant events for the work. All references to the literature, procedures, or other documents should be complete and traceable to each document and the specific section or pages identified. The following requirements also apply:

- Pages should be numbered consecutively and kept intact. (No page shall be left blank or removed from the notebook.)

- IEach page should be signed and dated by the person making the entry.

Records should be stored in a manner to preclude deterioration of the records. The following requirements apply:

- Provisions should be made in the storage arrangement to prevent damage from moisture, temperature, fire, and pressure.
- Records should be firmly attached in binders or placed in folders or envelopes for storage in slecl file cabincts or in containers on shelving.

- Provisions should be made for special processed records (c.g., radiographs, photographs, negatives, microfilm, and magnetic material) to prevent damage from excessive light, stacking, clectromagnetic fields, temperature, and humidity.

- Rules should be established governing aceess to and control of records.

- Methods should be established for filing supplemental information and disposing of superseded records.

\section{BIBLIOGRAPHY}

U.S. Department of Encrgy, DOE/LLLW-67'I, Site Characterization Hundbook. Washington, DC, June 1988.

U.S. Government Printing Ofrice, Code of Federul Regulations, Title 10, "Energy," Chapter 1, U.S. Nuclear Regulatory Commission, Parts () to 199, Washington, DC, revised annually.

U.S. Nuclear Regulatory Commission, NUREG-1199, Revision 1, Standard Format and Content of a License Application for a Low-Level Radioactive Waste Disposal Facility, Washington, DC, January 1988.

- -, NUREG-0902, Site Suitability, Selection und Characterization, April 1982.

- -, NUREG-1200, Revision 1, Standard Review Plan for the Review of a License Application for a Low-Level Radioactive Waste Disposal Facility, January 1988.

- -, NUREG-1293, Quality Assurance Guidance for Low-Level Radioactive Waste Disposal Facility, January 1989.

-D, NUREG/CR-2700, Parameters for Characterizing Sites for Disposal of Low-Level Radioactive Waste, May 1982.

- -, NUREG/CR-3038, Tests for Evaluating Sites for Disposal of Low-Level Radioactive Waste, December 1982.

American National Standards Institute/American Socicty of Mechanical Engineers, ANSI/ASME NQA-1-1986, Quality Assurance Program Requirements for Nuclear Facilities, New York. 


\title{
APPENDIX A
}

\begin{abstract}
SUMMARY OF PUBLIC COMMENTS ON DRAFT TECHNICAL POSITION STATEMENT (FEDERAL REGISTER, VOL. 54, NO. 237, DECEMBER 12, 1989, 54 FR 51033)
\end{abstract}


Commenter

John Greenberg

Brattleboro, VT

U.S. Department of the Interior, Office of Environmental Affairs, Washington, DC

Roland Cote Kennewick, WA

\section{Mivjor Comment}

The document should emphasize that the purpose of the site characterization process is to ensure the protection of the health and safety of the public in developing a low-level waste disposal facility.

The commenter discussed the Department of Interior's policy regarding testing at sites of low-level and toxic waste disposal.

Inconsistencies exist between this NURFG and related NUREGs although the cunmenter strongly supports these documents.

\section{NRC's Response}

NRC agrees, and the document has been revised to better emphasize the purpose of site characterization.

The purpose of NUREG-1383 is to provide guidance on the application of quality assurance principles to site characterization. This quality assurance document is not the appropriate document to communicate the policies of other agencies.

The NRC agrees that there is some inconsistency between NUREG-1383, NUREG-1293, and Chapter 9 of NUREG-1199 and NUREG-1200. The NRC is currently reviewing and evaluating all these documents for consistency and for consistency with 10 CFR Part 61. 


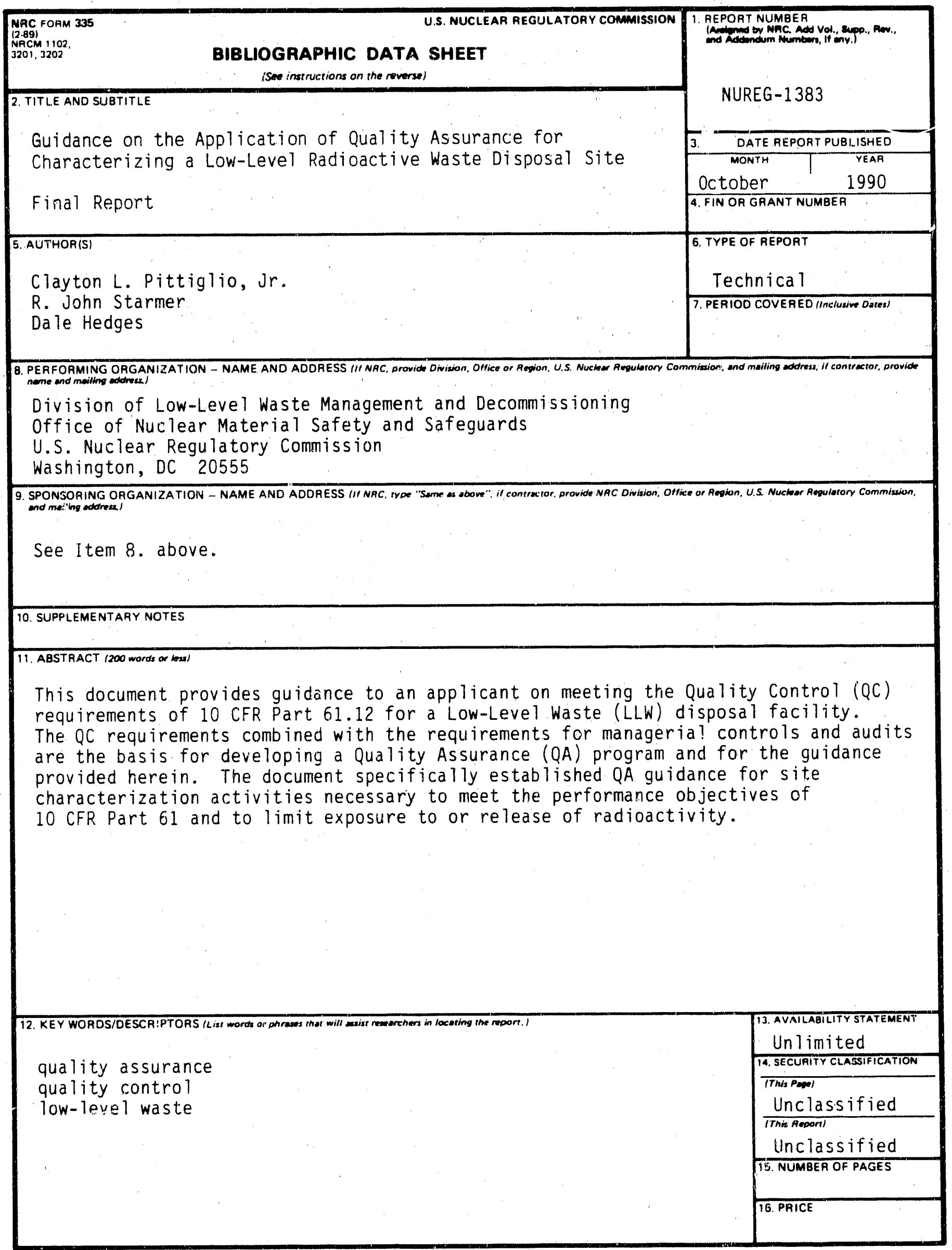



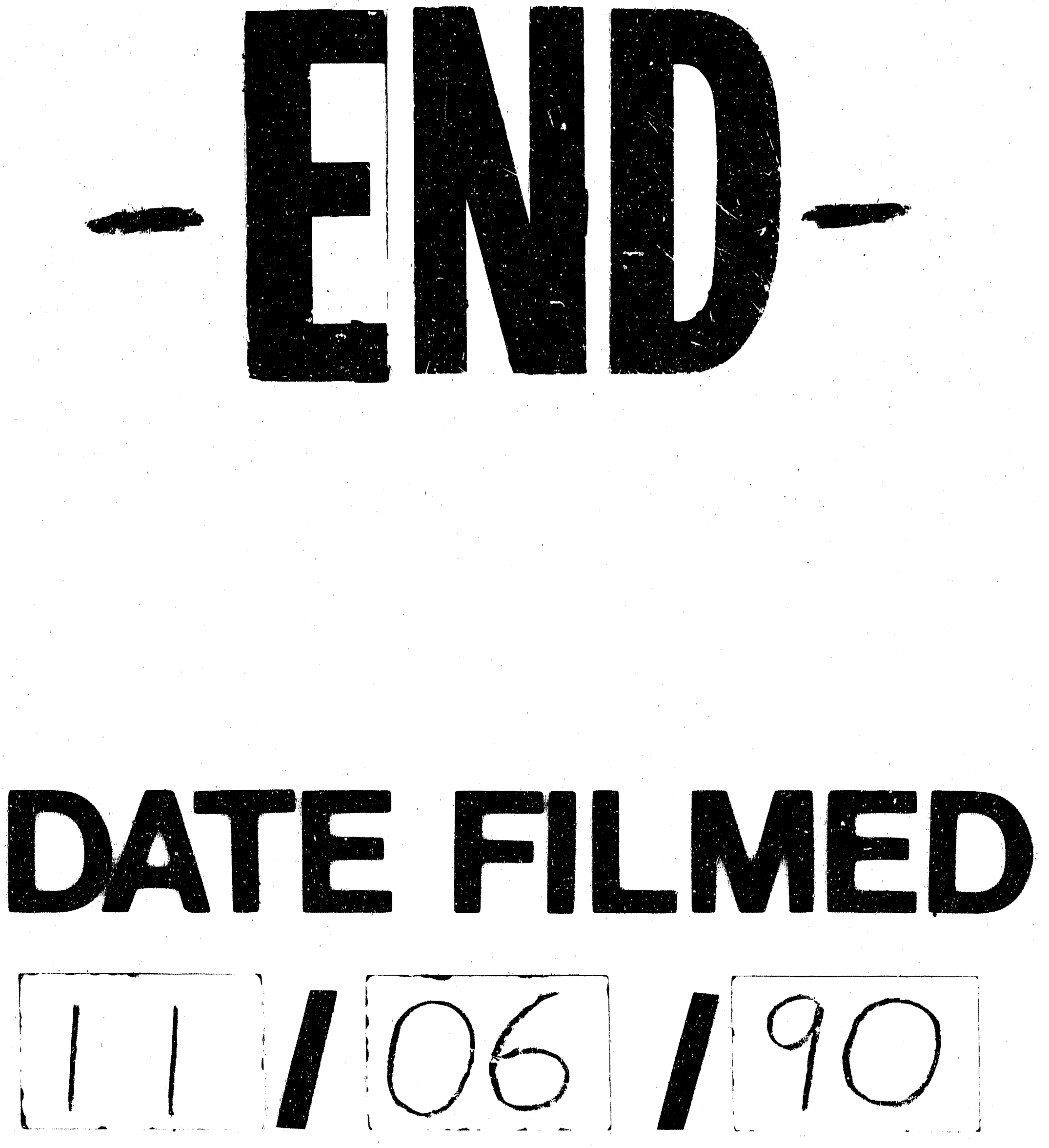
